\title{
内科学の展望（第15回）消化管疾患の診断と治療 最近の進歩
}

司会 山形大学医学部第二内科 石川 誠

III. 炎症性腸疾患

6. 感染性腸炎上抗生物質起因性大腸炎

\section{度恙義大孚医学部内科 土屋雅春}

感染性腸炎に関する研究の歴史は，人類が疾患 と徽生物々の因果関保を科学的に実証し，その病 態生理の解明，治療法の確立に心血を注いだ闘い の歴史である。この間, 病原微生物に対する武器 として抗生物質が登場した時この闘いに終止符が 打たれるのではないかと思われたが，この夢は耐 性菌の出現さらには抗生物質に起因する大腸炎が 認識されるに及び，碎かれるに至った。ささらに近 年, AIDSなど新しい疾病の出現之ともに, 感染性 腸炎の病原溇生物のスペクトラムも警異的に広 がっており，その闘いの歴史は新しい局面をむか えようとしている。

このよらな背景を念頭に㧍き，感染性腸炎なら びに抗生物質起因性腸炎の発症機序, 病態, そし て治療につき興味ある問題を取上げ解説したい。

\section{1. 感染性腸资}

急性感染性腸炎は表 1 亿挙げる上らに多くの病 原体によっておこる，細菌性のものは，細菌が腸 上皮細胞に侵入して増殖することにより生ずる細 胞侵入型，腸管内で増殖した細菌より産生された 毒素による生体内毒素産生型，扝よび食品内で細 菌が增殖して産生した毒素をヒトが摂取すること による食品内毒素産生型の3つに分類される。細 胞侵入型は保菌者や保菌動物の便で污染された食 品より感染し，比較的長い潜伏期をもつ。これに
対し食中毒型は比較的短い潜伏期で発症する。を の他, ウイルス, 原虫, 真菌によるものなどがあ るが，赤琍アメー・゙は輸入伝染病の観点から，ま た真菌や寄生虫はcompromized host，特にAIDS にみられることが注目される。

日本に打饬感染性腸炎の発症件数を及る と ${ }^{1)}$ ，腸炎ビブリオが最も多く（1985年に519件， 患者数14006人)，ブドウ球菌（163件，4968人）， サルモネラ菌(82件，2412人)と続き，これにキャ ンピロバタターと病原大腸菌を合わせ全体の $90 \%$ 以上を占める。杰た小児では，サルモネラやキャ ンピロバクターが多くみら机るのに対し，成人で は腸炎ビブリオが大部分であるといら特徵があ る.

最近の動向として，海外からの㷌国者，入国者 による輸入感染症が増加していることが举げら れ，特に細菌性赤浰では約半数が輸入例と考学ら れる。ここで著者らが日米医学協力研究会コレラ 専門部会にて臨床的基礎的研究にたつささわってき たコレラ下㢉症をとり挙げ最近の知見について述 ベる2!.

1884年，長崎県での大流行を機会に，初めて日 本でコレラ菌を発見し予防行政に尽くしたのは北 里柴三郎博士であるが，コレラ下㢉症の機序が分 子レベルで解明される契機は1960年代のEltor型

Review on Internal Medicine (1987) Recent Progress in Diagnosis and Treatment of Digestive Diseases.

III. Inflammatory bowel diseases.

Chairman: Makoto Ishikawa, The Second Department of Internal Medicine, Yamagata University School of Medicine, Yamagata.

6. Infectious diarrhea and antibiotics-associated colitis.

Masaharu Tsuchiya, The Department of Internal Medicine, School of Medicine, Keio University, Tokyo. 
表 1 ，感染性腸农の分類

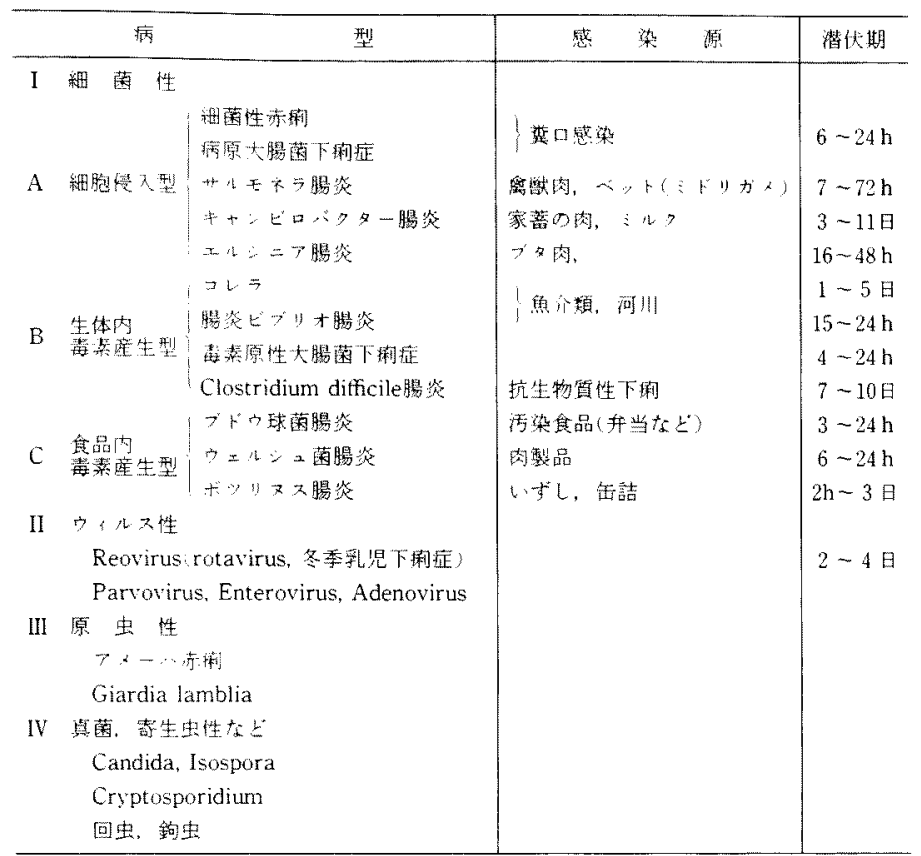

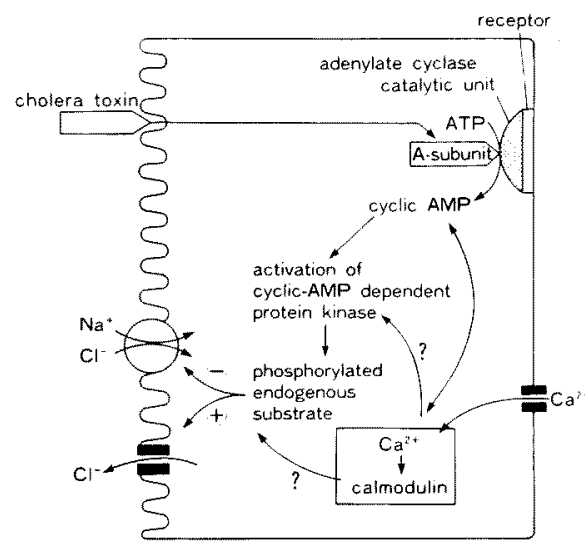

図 1.Cholera toxinに上る分泌性 下峲心機序
コレラが世界的に流行したことによる。

コレラ下痢症はコレラ菌の産生するコレラ毒素 により若起される。コレラ毒素は分子量 840000 蛋 白質で，A (active)とB(binding)の 2 つのsubunit からなり，B subunitが上皮細胞膜に存在するGanglioside GM1の特異的レセプターに結合するが, 最近教室の森田により ${ }^{3}$ 細胞膜の glycoprotein む レセプターになることが明らかにされた。Asubunitはその後細胞内入入り, basolateral membraneに豊富に存在するadenyl cyclaseを活性化 し，細胞内cyclic AMPの上昇をむたらす。cyclic AMP濃度が上昇すると，それがcyclic AMP dependent protein kinase (A-kinase) 活性化 し,さらに上皮細胞内の未知な物質をりン酸化し, 上皮細胞膜での $\mathrm{Na}^{+}-\mathrm{Cl}^{-}$輸送を抑制し, $\mathrm{Cl}^{-}$分泌を 増強し過分泌が生ずる(図 1) ${ }^{4}$. Cyclic AMPを介 する下四の発症機序は，コレラ毒素のみならず， 大腸菌の易熱性エンテロトキシン(LT), VIP, 脂 肪酸, 胆汁酸によって生ずる下痢にも関与してい ることが知られ，臨床的にす注目を浴びている。 コレラ毒素の空腸内投与によるラットの分泌性
下莉の実験で，著者らはこの下塺が， somatostatinやloperamide（ロペミン）で抑制されること を最近明らかにした (図 2$)^{5}$. コレラ毒素は粘膜 内cyclic AMPを上昇させるが, 興味深いことにこ れら萝物は粘膜のcyclic AMP濃度の上昇に関係 なく作用する。さらにラット小腸より分離した刷 子縁（brush border）用いてA-kinase活性にこ れら薬物が影響を及ぼすか否かをin vitroでみた が、A-kinaseへの直接作用はみられなかった。こ のことは somatostatin やloperamide は cyclic AMP とは別の機序を介して小腸分泌過程を抑制 していることを示唆している。

他方，ア七チルコリンやセロトニンによる下誗 はcalcium-calmodulin系を介して生ずる、 $\mathrm{Ca}^{++}$. calmodulin系が, A-kinaseの活性化の後，それと 連動して働いており， somatostatinやloperamide がそこへ作用している可能性乎ある。このような 薬物は治療的に使兄る可能性もありさらに娭討を 進めたい.

さて, 細胞レベルでの水電解質の分泌機序があ る程度理解でさたとしても，実際の著者らのフィ 


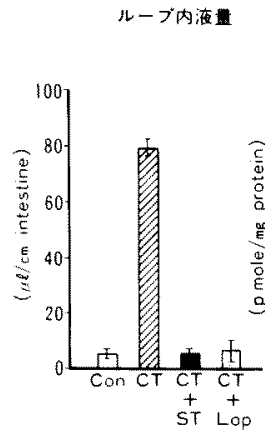

粘䐙内 cyclic AMP

Cyclic AMP依存性 protein-kinase活性

図 2.ラット小腸ルーブに拈けるコレラトキシン (CT) 意起性分泌性下脷上粘膜内cyclic AMP, cyclic AMP依存性 protein-kinase活性, ーソマトスタチン (ST)とロベラマイド（Lop）の影響-

リピンやバングラディシュでのヒトコレラ症の経 験から，実験モデルと実際の患者の病態の間に ギャップが存在することに気付く，小腸内視鏡で コレラ症患者の空腸を観察すると、蠕動運動の著 明な九進とともに，浮腫状の粘膜にところどころ erosionや斑状発赤がみられ，空腸生検で絨毛が葉 状に融合するよらな変化も一部に文られだ、。従 来Gangarosa一派がコレラ下峲症においては，細 胞内代謝が変化するのみで粘膜に形態的変化が起 きないといら定説を立てていたが，著者らは空腸

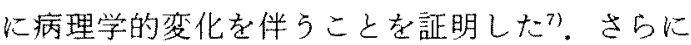
空腸粘膜組織の電顕的娭討では8，警いたことに 腸上皮細胞内の処々に穴があき上皮細胞間隚開 大し，腺窩の部位でも管空側へ原形質突起が飛び 出し，やがてをの突起が膜に包まれ，ポンと腸管 内腔へ放出さ机てゆく像が少られた、ラットに求 ける実験毛デルに拈いても小腸上皮の形態的変化 がみられる。すなわら，免疫組織化学による電顕 的手法で，小腸刷子縁のalkaline phosphataseを 特異的抗体にて検索すると，刷子縁膜上のみなら ざ，腸管腔内の膜様物上にも古られ， alkaline phosphataseが腸管内に盛んに放出されているこ とが証明された (图 3$)^{9)}$.

ヒトコレラ症に拈ける1日数りットルにも及ぶ 下利は単に細胞内のイオンの動きだげは説明で きず，以上述べたような形態学的変化を伴い，さ らに小腸の微小偱環の透過性え進を伴らと思われ
る。さらに著者らはフィリピン拉よびバングラデ シュのコレラ症患者に扔いて，急性期に和ける血 清enteroglucagon檤の上昇を認めて㧍り，消化管 ホルモンの分泌性下脷における関与む重視され权 ばならない10.

以上コレラ下㢉症の理解には，細胞内での toxinの作用のみならず,全身的な機能の变動も病 態を作り上げていると考之ることが大切である。

コレラの研究の進歩とともに，大腸菌による下 浰症の研究も進灭, 中でも旅行者下痢症 (traveler' s diarrhea）や乳幼児下痢症の病原菌として有名 な毒素原性大腸菌(ETEC)は，コレラ毒素類似で， cyclic AMPを介して動くLT毒素（heat-labile toxin) とcyclic GMPを介して働くST毒素 (heatstable toxin）の2 種類を産生し，そのtoxinによ り分泌性下脷孔惹起することが知られる。教室の

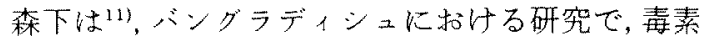
原性大腸菌下痢症患者に扎いても，内視鏡的に小 腸に発赤やerosionが観察されることおよび上皮 細胞の永脱，粘膜固有層での充血と細胞浸潤など の組織的変化が存在することを明らかにした。

次に, 海外交流による輸入感染例とくに, homosexual間での感染が注目されるAIDSやアメーバ 赤㢉などの疾患について話を移したい。

AIDSは human immunodeficiency virus (HIV) により蒬き起こされる重症の免疫不全をきたす疾 患であるが，性行為とくにホモセクシュアリティ に関連して起こることより全世界の注目を浴び た。この際の免疫異常は，遅延型アレルギーの異 常，T-cell系ではhelper Tの著明な堿少とそれに 伴 万 suppressor Tの相対的比率の增加が特徽的 で，B-cell系の方は余り変化しないといわれてき たが，奏際快IgA，IgGなど高い例がみられる。免 疫機能の低下を反映して本症では多彩な病原体に よるopportunisticな腸管感染症が生じ，下痢，下 血が患者を恼市す主症状となり光る。真菌では Candida albicans，ウイルスではCytomegalovirusやHerpes simplex, 寄生虫ではCryptosporidiumやIsospora belli，細菌ではMycobacterium avium-intracellulareなどが, 主要病原体として多 


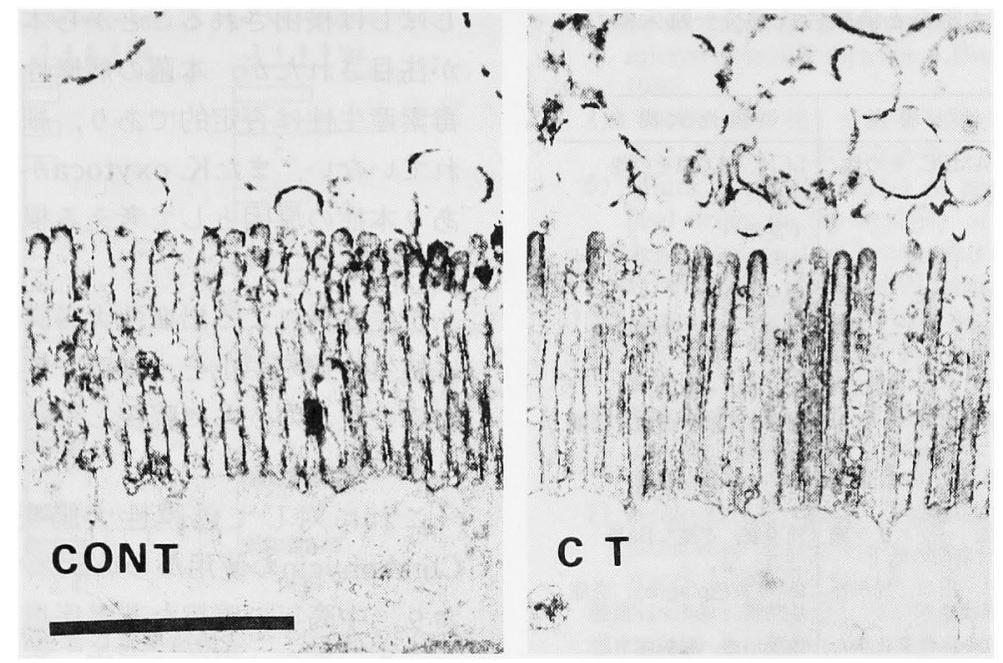

図 3 .小腸吸収上皮細胞媺䄉毛膜のアルカリフォスファターピの免度電顕による検 討9!.コレラトキシン (CT) 投与後, 微䄉毛上方の管腔内に多量のALP陽性膜様物が 認められる $(\mathrm{Bar}=1 \mu \mathrm{m})$.

く報告されている12). AIDSのみならず, common variable immunodeficiencyやIgA 欠損症などの 免疫不全症候群に打いても感染性腸炎は主要な問 題であり, 今後も抗腫瘍療法や臟器移植の発展に 伴い, ますます腸管のopportunistic infectionは重 視されるべきであろう。军たAIDS患者の下㢉や 消化管出血は原病による消化管病変や, Kaposi肉 腫, lymphomaによるものと鑑別されなければな らず, 病原体の検出も新しい技術が要求される時 代となりつつある。

アメーバ性大腸炎は本邦では比較的まれとされ てきたが，近年，厚生省伝染病統計をみても 1975 年 9 例, 80 年 25 例, 83 年79例と増加の一途をたどっ ており,輸入感染症として再び注目をあびている。 しかし, 東南アジア方面からの輸入例とともに, 原因不明な国内感染例子増加しており，この点に つき竹内ら $\left.{ }^{13}\right)$ は赤片アメーバ血清反応陽性の日本 人症例の約 $40 \%$ がTPHA, FIA-ABS陽性であり, かつ近年男性例が目立つことより, 男性間におけ るsexually transmitted diseaseの可能性を強調 している.

急性感染性腸炎の治療として, 全般に自然治癒 の傾向が強いので赤㢉, コレラおよび重症サルモ
ネラ以外原則として抗菌製剤は必ずしも必要とし ない，脱水に対しては電解質を含む輸液が必要で あり，乳酸加リンゲル液が有効である。また下利 は生体防御反応でもあり, 整腸薬, 鎮㾏薬など用 いても，止痢薬は原則として使用しない。公衆衛 生の観点のみならず, 治療面においても細菌性赤 峲，アメーバ赤誗，コレラなどは絶対に見逃して はならない疾患であり, 診療に際し常に念頭にお く必要性を強調したい。

\section{2. 抗生物質起因性大腸炎}

次に抗生物質起因性大腸炎について述べるが, 抗生物質の内服後に下痢を主とする消化器症状を 来すことは従来より指摘されていた。古くは菌交 代性ブドウ球菌性腸炎が問題となっていたが, 1970年代より主に欧米において腹部手術や重篤な 全身性疾患に偽膜性大腸炎が合併することが注目 されはじめ, さらに本症がLincomycin やClindamycinによる菌交代症の結果 Clostridium difficileの増殖, その産生毒素により惹起されるこ とが明らかにされた ${ }^{14) 15)}$. 一方本邦では主として 合成ペニシリンによる出血性大腸炎の報告が戸 谷 ${ }^{16)}$ あいは我々のグループ17)によりなされた が，偽膜性大腸炎との異同や成因に関して議論が 
表 2，急性出血性大腸炎上偽膜性大腸炎一臨床像の 比較一 ${ }^{\text {到 }}$

\begin{tabular}{|c|c|c|}
\hline & 出利性大腸炎 & 媯膜性大腸炎 \\
\hline 抗生物澌 & ABPC, AMPC，その他 & LCM, CLCM \\
\hline 発生類度 & 本邦に多い & 欧米に多い \\
\hline 好発知命 & 青扗年 & 中商年 \\
\hline 性 & $9>3$ & $p=t$ \\
\hline 校 & 架然発症 & 般徐心発拝 \\
\hline 怔 & 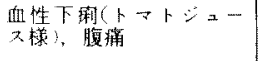 & 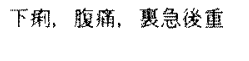 \\
\hline 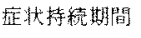 & $2 \sim 7 日$ & 7 日以上一数媴 \\
\hline 模直成精 & 白血球增加 & 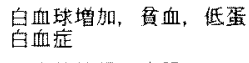 \\
\hline 好発部位 & $\begin{array}{l}\text { 下存結腸より口側，直腸 } \\
\text { 等な }\end{array}$ & S字状結腸。直晹 \\
\hline X 線所見 & 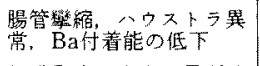 & 壁不整，不整なBa斑 \\
\hline 内視鏡所胃 & 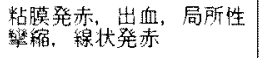 & 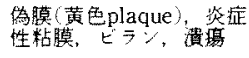 \\
\hline 生强組䄳所見 & 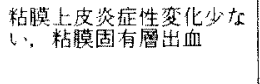 & 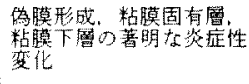 \\
\hline 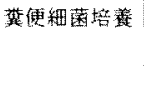 & 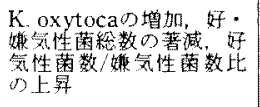 & Cl. difficileo \\
\hline 团 & 不＼cjkstart明 & Cl. difficile toxin \\
\hline 旗 & 対拝瘵法 & 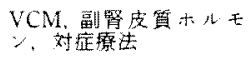 \\
\hline 缕 & 良 & 死亡例志り \\
\hline
\end{tabular}

進行中である。

表 2 にその病像の差異をまとめた。ず出血性 大腸炎はABPC队Cephem系抗生物質などにより 若起され，本邦に招いて報告数が多く，青壮年の 男性に多発している。突然の血性下㢉により発症 し腹痛を伴い, X線上腸管揧縮や八ウストラの異 常などが認められ，thumb printing像など虚血性 腸炎類似の所見となることもしばしばある。内視 鏡的には浮腫, 発赤, 出血が認められ, 病変部の 近傍に血管透見可能な正常粘膜像がみられること も特徵の一つである。病変の分布は横行結腸一S 状結腸にかけてが主で，直腸には病変が認められ ない，大腸粘膜組織所見では粘膜固有層の出血が みられ全体に炎症性細胞浸潤の程度は比較的軽度 であり，症例によっては好酸球浸潤の目立つこと もある。またびらんは見られるものの潰瘍や偽膜 はみられない。

本症の䔬便細菌培養所見の特徵は好気性, 嫌気 性菌総数の著减であり，また好気性菌数/嫌気性菌 数の比が上昇することである。またK. oxytocaが
しばしば検出されることから本症の発生との関連 が注目されたが，本菌の病原性に関しては腸管内 毒素産生性は否定的であり，細胞侵入性も確認さ れていない。またK. oxytocaが証明されない例車 あり本症の原因として考学る根拠は今のところ非 常に乏しい。

抗生物質に上る出血性大腸炎の臨床経過の特徴 は抗生物質の中止と, 補液や整腸薬など対症療法 のみで数日のらちに軽快し，予後は極めて良好な ことである.

これに対して偽膜性大腸炎はLincomycinや Clindamycinの使用が多い欧米で多く報告されて 扣り，中高年の重篤な基礎疾患をもつ者に発生し ている、発症は緩徐で下痢，腹痛，発熱などを呈 し出血は少ない，貧血や低蛋白血症を伴いS状結 腸から直腸に主病变を認める。病变の特徵は内視 鏡的に黄色調の偽膜形成，びらん，潰瘍などを認 め, 病変部は全体に浮腫状である。病理組織学的 には粘膜固有層および粘膜下層に著明な资症細胞 浸潤を認め，偽膜が証明される。

䔬便細菌培養では，蔂便1g中総菌数の著明な減 少に加え, Clostridium difficileが検出され, 治療 により軽快挠は総菌数の増加とClostridium difficileの陰性化が認められる (図 4$)^{18 \text {. }}$.

本症の発生がClostridium difficileの産生する toxinkよるものであることはすでに多くの事実 より確立された概念であるが，そのtoxinには enterotoxin とcytotoxinの少なくとも2 種類につ いて検討が進んでいる(5)191。 。ずenterotoxinは toxin AまたはD-1ともいわれ, cholera toxinやE. coliのLT (易熱性毒素) に代表される enterotoxin としての特徵を有しており, ウサギ結禁腸管ルー プ試験陽性，ウサギ皮膚血管透過性陽性を示し， 八ムスターの盲腸部に投与すると液の貯留ととも に中等度の出血性病変を形成する。一方cytotoxin はtoxin B⿱たはD-2ともいわれ培養細胞变性作 用が強く，八ムスタ一の盲腸部に投与すると下浰 はおこさず，著明な出血性病变のみを形成する。

偽膜性大腸炎の経過は重篤で死亡することもし ばしばあり，Clostridium difficileに対するVan- 


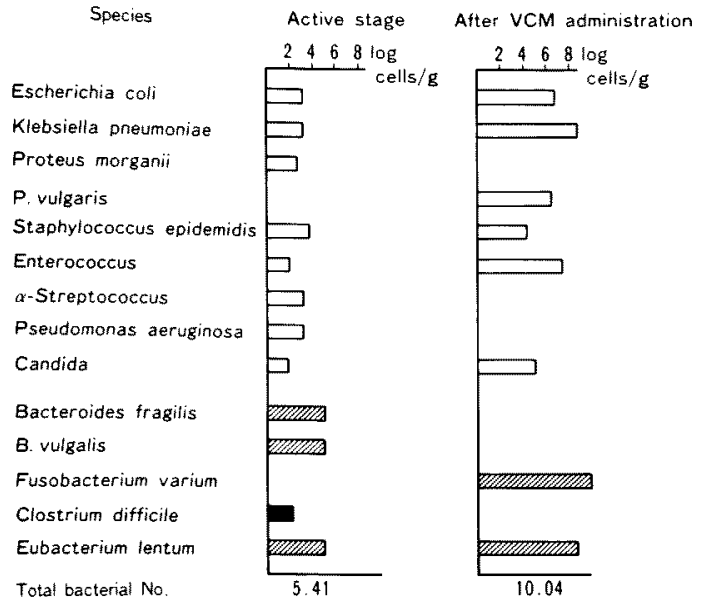

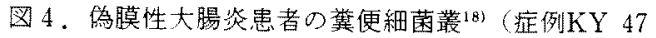
才，女性

急性期上VCM ベンコマイシン)投与後の变化

comycinの投与や副腎皮質ホルモンの投与などが 必要となる。

この上5に偽膜性大腸炎の病態はかなり明ら力 となってきている一方, 出血性大腸炎の発生機序 についてはなお不明な点が多いままた5した病 態の差が個体の条件により生じてきている可能性 もあり，生体側の反応様式の違いについてもbっ と検討されるべきである。

以上感染性腸炎と抗生物䆩起因性腸资について 我々の考方方を述へ，いろいろな疾患寺してき たが，こうした古くて新しい病態の解明にはまだ 更に多くの研究者の努力を要する。しかしこうし た努力の中から得られる成果は，腸上皮細胞と toxinの interactionおよび細胞内mediator $の$ 研究 といった膨大な業績につながってきている。この 方面での研究がさらに進展することを新りつつ, またその臨床応用に果すべき我々の役割を痛感し ている。

協同研究者: 三浦總一郎, 渡辺 守, 斎藤英扸, 朝倉 均, 日比紀文，森下鉄夫

\section{文献}

1) 1985年厚生省伝染病統計.

2）土屋雅春：ヒトコレラ症をめぐる最近の話題．消 化器臨本生理 $5: 37,1981$.

3) Morita A, et al: Identification of cholera toxin binding glycoproteins in rat intestinal microvillus membranes. J Biol Chem 255 : 2549 1980.

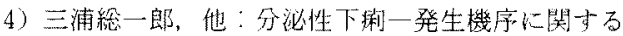
新しい見解一。医学のあ内及 $139: 998,1986$.

5) Miura $S$, et al: Effect of anti-secretory diarrheal drugs on the activity of cyclic-nucleotide dependent protein kinase in rat small intestine. Proceedings of the 22th Joint Conference, US. Japan Cooperative Medical Science Program, Cholera Panel. KTK Science Publishers Tokyo, 1986 (in press).

6) Morishita T, et al: Endoscopy of the jejunal mucosa in human cholera. Gastrointestinal Endoscopy $24: 284,1978$

7) Asakura $\mathrm{H}$, et al: Pathologic findings from intestinal biopsy specimens in human cholera. Amer J Dig Dis 18: 271, 1973.

8) Asakura $\mathrm{H}$, et al : Electron microscopic study on the jejunal mucosa in human cholera. Gut $15: 531,1974$.

9）浜田愿城：ラットに打忛るコレラトキンン惹起性 分泌性下浰症の小腸アル力!フォスファターゼの 分泌扰よび生合成え進についてて、日消病会誌 84 ; 221, 1987.

10) Morishita T, et al: Enteroglucagon, VIP and secretin in cholera. Kuwahara $\mathrm{S}$, et al, ed, Advances in Research on Cholera and Related Diarrheas, Vol 3, KTK Scientific Publishers, Tokyo, 1986, p317.

11) Morishita $T$, et al: Pathology of the jejunum in human cholera. ETEC and NAGV diarrhea. Kuwahara $S$, et al, ed, Advances in Research on Cholera and Related Diarrheas, Vol 2, KTK Science Publishers, Tokyo, 1985, pl87.

12) Weinstein WM: Acquired immunodeficiency syndrome and the gastrointestinal tract. Kasuya $Y$, et al, ed, Gastrointestinal Function. Regulation and Disturbances, Vol 5, Excerpta Medica, Amsterdam 1987, p3.

13）竹内勤，他：赤利 $7 \times-$ 症の血清学的骖断. Immuno-advance $12: 27,1983$.

14) Bartlett JG, et al: Clindamycin-associated colitis due to a toxin-producing species of clostridium in hamsters. J Infect Dis 136: 701, 1977.

15) Sullivan NM, et al: Purification and charac. terization of toxins $A$ and $B$ of clostridium difficile. Infect Immun 35: 1032, 1982.

16) 戸谷徹造：Klebsiella oxytocaによる急性出血性 大腸炎。日本臨玬 $36: 1308,1978$.

17）鈴木紘一，他：抗生物質に上る急性出血性大腸炎 の病態之成因。第 1 報。急性出血性大腸炎の臨床 像. 医療 $37: 755,1983$.

18）鈴木紜一，他：抗生物質による急性出血性大腸炎 の病態之成因。第2 報。Clostridium difficile毒素 を模出し古た榩膜性大腸炎と急性出血性大腸炎と の対比。医療 38:152, 1984.

19) Wilkins TD: Role of clostridium difficile toxins in disease. Gastroenterology 93: 389, 1987. 